Research Article

\title{
Study on awareness regarding gender based violence among group D workers in public hospitals of Delhi, India: a gender perspective
}

\author{
M. Meghachandra Singh ${ }^{1}$, Suneela Garg${ }^{1}$, Rozaleen Dash ${ }^{1}$, Rajesh Kumar ${ }^{1}$, Nidhi Jain ${ }^{1}$, \\ Nandini Sharma ${ }^{1}$, Tanu Anand ${ }^{2}$
}

${ }^{1}$ Department of Community Medicine, Maulana Azad Medical College, New Delhi, India
${ }^{2}$ Department of Community Medicine, North Delhi Municipal Corporation Medical College, Delhi, India

Received: 08 April 2016

Accepted: 07 May 2016

*Correspondence:

Dr. M. Meghachandra Singh,

E-mail: megharita1@gmail.com

Copyright: (c) the author(s), publisher and licensee Medip Academy. This is an open-access article distributed under the terms of the Creative Commons Attribution Non-Commercial License, which permits unrestricted non-commercial use, distribution, and reproduction in any medium, provided the original work is properly cited.

\begin{abstract}
Background: Gender based violence (GBV) is a global public health concern. It is the most common type of violence against women with adverse consequences on physical, mental and sexual health. Hence, this study was conducted to assess awareness on various aspects of GBV among Group -D workers in hospitals of Government of National Capital Territory (NCT), Delhi, India.

Method: A cross-sectional study was conducted among 167 Group-D workers in nine hospitals of Government of NCT, Delhi selected randomly by population proportionate to size and giving informed consent. A pre-tested semistructured interview schedule collected the data. Data was entered in MS-excel and analyzed using SPSS version 17. The relationships between awareness and socio-demographic variables were assessed using Chi-square test and Fisher's exact test.

Results: Awareness about different Acts related to GBV among Group -D workers was not satisfactory. 30.7\% males were aware about Domestic Violence Act 2005 as compared to 15.2\% among females $(\mathrm{p}<0.05)$. Awareness among females was higher than males regarding physical, emotional and sexual types of GBV $(\mathrm{p}<0.05)$. Female respondents were significantly more aware than males about risk factors of GBV viz. male control in decision making, financial dependence on the husband/spouse, poverty/low socio economic status $(p<0.05)$. Females were significantly more aware than males regarding various health effects of GBV.

Conclusion: The study findings suggest the need for creating awareness among the study population regarding various aspects of GBV so that they can contribute in providing effective care of victims of GBV in the government hospitals.
\end{abstract}

Keywords: Awareness, GBV, Group -D workers, Risk factors, Health effects

\section{INTRODUCTION}

The Declaration on elimination of violence against women adopted by the UN General Assembly in 1993, defines violence against women as any act of gender based violence against women that results in or is likely to result in physical, sexual or psychological harm or suffering to women, including threats of such acts, coercion or arbitrary deprivations of liberty, whether occurring in public or private spaces. ${ }^{1,2}$ Gender-based violence (GBV) is a global public health concern that has recently received significant research and policy 
attention. According to WHO report, among women aged 15-44 years, gender violence accounts for more deaths and disability than cancer, malaria, traffic injuries or war put together. ${ }^{3}$

GBV is a complex and multidimensional problem embedded within the broader socio-economic, political and cultural context with traditional norms. Female empowerment might increase GBV temporarily when traditional gender roles are challenged, but living in a community where women are empowered and have higher socio-economic status is protective against GBV. ${ }^{4,5}$ Poverty and lack of economic opportunities make men more likely to engage in violence and substance abuse, increasing the risk of GBV (World Bank, 2000). The odds of domestic violence are about six times higher when the husband gets drunk frequently. ${ }^{6}$ The large majority of GBV takes place in the home, where the victim often experiences repeated attacks. ${ }^{7}$ Men might be exposed to GBV but the health impacts on women are often more severe. ${ }^{8} \mathrm{GBV}$ is very common, but most health care providers fail to diagnose and register GBV, not only due to socio-cultural and traditional barriers, lack of time, resources and inadequate physical facilities; but even more so due to lack of awareness, knowledge and poor clinical practices with limited direct communication and failure to do a full physical examination, not to mention register and monitor the effectiveness and quality of care. Further the fear of violence and stigma reduces many victims' willingness to use health services WHO, $1998 .^{9}$

GBV against women is the most prevalent form of violence against women and it is a global human rights and public health concern. ${ }^{10,11}$ GBV affects physical, mental and reproductive health. Health consequences can be fatal and end in suicides. In India the issue has been highlighted with the Protection of Women from Domestic Violence Act in 2005. Different studies conducted in India indicates the association of GBV with different socio demographic factors. ${ }^{12-15}$ Employed women have been found to report violence more frequently than unemployed women in a number of other studies. ${ }^{16,17}$ There are still grey areas in the understanding of GBV, its various forms and different risk factors behind it. Through this study we attempt to estimate the proportion of knowledge of Group -D workers among hospitals of NCT (National Capital Territory), Delhi regarding awareness about GBV and the risk factors to become GBV victims. Objective of the study is to assess the awareness about GBV, risk factors and associated health effects among Group -D workers in selected hospitals of NCT, Delhi.

\section{METHODS}

The study was a cross sectional study conducted among Group-D workers in nine hospitals in Govt. of NCT, Delhi. The study was approved by the Institutional Ethics Committee, Maulana Azad Medical College, Delhi, India.
The hospitals were selected from a list prepared for the study. There are 34 hospitals including two Homeopathic hospitals and one Ayurvedic and Unani hospital having 50 beds or above under govt. of NCT Delhi. Out of these, 9 hospitals were randomly selected. The number of study participants in this category was determined based on the PPS sampling and they were selected from hospitals selected for the study. Based on the interim information on manpower of the hospitals, we included $20 \%$ of the staffs in Group-D category. Written informed consent was taken from each study participants. Interview was done in both Hindi and English language using a semistructured questionnaire. Questionnaire was based on awareness and health effects regarding GBV and its related issues. Guidelines of World Health Organization, including the importance of ensuring confidentiality and privacy, both as means to protect safety of study participants and to improve quality of the data were followed.

\section{Statistical analysis}

Data collected was entered in MS- excel spread sheet and data was analyzed using SPSS version 17 software. The relationships among related variables were assessed using Pearson Chi-square test and Fisher's exact test. 'p' value less than 0.05 was considered statistically significant.

\section{RESULTS}

Table 1: Distribution of awareness about domestic violence act 2005 and sexual harassment act 2013 in the study population.

\begin{tabular}{|c|c|c|c|c|}
\hline \multirow{2}{*}{$\begin{array}{l}\text { Characteristics } \\
\text { / } \\
\text { Gender }\end{array}$} & \multicolumn{2}{|c|}{ Awareness } & \multirow{2}{*}{$\begin{array}{l}\text { Total } \\
\text { No } \\
(\%)\end{array}$} & \multirow{2}{*}{$\begin{array}{l}\text { 'P' } \\
\text { value }\end{array}$} \\
\hline & $\begin{array}{l}\text { Yes } \\
\text { No } \\
(\%)\end{array}$ & $\begin{array}{l}\text { No } \\
\text { No } \\
(\%)\end{array}$ & & \\
\hline \multicolumn{5}{|c|}{ Domestic Violence Act } \\
\hline Male & $\begin{array}{l}31 \\
(30.7)\end{array}$ & $\begin{array}{l}70 \\
(69.3)\end{array}$ & $\begin{array}{l}101 \\
(100.0)\end{array}$ & \multirow[t]{2}{*}{0.02} \\
\hline Female & $\begin{array}{l}10 \\
(15.2)\end{array}$ & $\begin{array}{l}56 \\
(84.8)\end{array}$ & $\begin{array}{l}66 \\
(100.0)\end{array}$ & \\
\hline Total & $\begin{array}{l}41 \\
(24.6)\end{array}$ & $\begin{array}{l}126 \\
(75.4)\end{array}$ & $\begin{array}{l}167 \\
(100.0)\end{array}$ & \\
\hline \multicolumn{5}{|c|}{ Sexual Harassment Act } \\
\hline Male & $\begin{array}{l}18 \\
(17.8)\end{array}$ & $\begin{array}{l}83 \\
(82.2)\end{array}$ & $\begin{array}{l}101 \\
(100.0)\end{array}$ & \multirow[t]{2}{*}{0.32} \\
\hline Female & $\begin{array}{l}8 \\
(12.1)\end{array}$ & $\begin{array}{l}58 \\
(87.9)\end{array}$ & $\begin{array}{l}66 \\
(100.0)\end{array}$ & \\
\hline Total & $\begin{array}{l}26 \\
(15.6)\end{array}$ & $\begin{array}{l}141 \\
(84.4)\end{array}$ & $\begin{array}{l}167 \\
(100.0)\end{array}$ & \\
\hline
\end{tabular}

One hundred sixty seven Group -D workers were enrolled for the study. Out of 167 study subjects $101(60.5 \%)$ were males aged 21-60 years and $66(39.5 \%)$ were females aged 18-65 years. Table 1 shows the distribution of awareness about Domestic Violence Act 2005, among respondents. Out of 167 Group - D workers, 30.7\% males 
were aware about Domestic Violence Act 2005 as compared to $15.2 \%$ among females and this was found to be statistically significant $(\mathrm{p}=0.02)$. Awareness regarding Sexual Harassment Act 2013, however, did not show significant association between the gender $(\mathrm{p}=0.32)$.

Table 2: Awareness about different types of gender based violence among respondents.

\begin{tabular}{|ccccc|}
\hline $\begin{array}{c}\text { Types of } \\
\text { gender } \\
\text { based } \\
\text { violence }\end{array}$ & $\begin{array}{c}\text { Male } \\
\text { No }(\%) \\
\mathbf{n}=\mathbf{1 0 1}\end{array}$ & $\begin{array}{c}\text { Female } \\
\text { No }(\%) \\
\mathbf{n}=66\end{array}$ & $\begin{array}{c}\text { Total } \\
\text { No }(\%) \\
\mathbf{n = 1 6 7}\end{array}$ & $\begin{array}{c}\text { 'p' } \\
\text { value }\end{array}$ \\
\hline Physical & $33(32.7)$ & $31(47.0)$ & $64(38.3)$ & 0.07 \\
\hline Economical & $4(4.0)$ & $3(4.5)$ & $7(4.2)$ & $1.00^{*}$ \\
\hline Emotional & $4(4.0)$ & $8(12.1)$ & $12(7.2)$ & $0.06^{*}$ \\
\hline Sexual & $20(19.8)$ & $14(21.2)$ & $34(20.4)$ & 0.85 \\
\hline Verbal & $40(39.6)$ & $10(15.2)$ & $50(29.9)$ & 0.001 \\
\hline
\end{tabular}

Table 3: Gender-wise awareness on risk factors for gender based violence.

\begin{tabular}{|c|c|c|c|c|}
\hline \multirow{2}{*}{$\begin{array}{l}\text { Risk } \\
\text { factors/ } \\
\text { Gender }\end{array}$} & \multicolumn{2}{|l|}{ Response } & \multirow[b]{2}{*}{$\begin{array}{l}\text { Total } \\
\text { No }(\%)\end{array}$} & \multirow[b]{2}{*}{$\begin{array}{l}\text { 'P' } \\
\text { value }\end{array}$} \\
\hline & $\begin{array}{l}\text { Yes } \\
\text { No }(\%)\end{array}$ & $\begin{array}{l}\text { No } \\
\text { No }(\%)\end{array}$ & & \\
\hline \multicolumn{5}{|c|}{ Alcohol use } \\
\hline Male & $90(89.1)$ & $11(10.9)$ & $101(100.0)$ & \multirow{3}{*}{$0.41 *$} \\
\hline Female & $62(93.9)$ & $4(6.1)$ & $66(100.0)$ & \\
\hline Total & $152(91.0)$ & $15(9.0)$ & $167(100.0)$ & \\
\hline \multicolumn{5}{|c|}{ Substance use } \\
\hline Male & $79(78.2)$ & $22(21.8)$ & $101(100.0)$ & \multirow{3}{*}{0.11} \\
\hline Female & $58(87.9)$ & $8(12.1)$ & $66(100.0)$ & \\
\hline Total & $137(82.0)$ & $30(18.0)$ & $167(100.0)$ & \\
\hline \multicolumn{5}{|c|}{ Male control in decision making } \\
\hline Male & $47(46.5)$ & $54(53.5)$ & $101(100.0)$ & \multirow{3}{*}{0.002} \\
\hline Female & $47(71.2)$ & $19(28.8)$ & $66(100.0)$ & \\
\hline Total & $94(56.3)$ & $73(43.7)$ & $167(100.0)$ & \\
\hline \multicolumn{5}{|c|}{ Financial dependence on the husband/ spouse } \\
\hline Male & $62(61.4)$ & $39(38.6)$ & $101(100.0)$ & \multirow{3}{*}{0.02} \\
\hline Female & $52(78.8)$ & $14(21.2)$ & $66(100.0)$ & \\
\hline Total & $114(68.3)$ & $53(31.7)$ & $167(100.0)$ & \\
\hline \multicolumn{5}{|c|}{ Poverty/ Low SES } \\
\hline Male & $69(68.3)$ & $32(31.7)$ & $101(100.0)$ & \multirow{3}{*}{0.02} \\
\hline Female & $56(84.8)$ & $10(15.2)$ & $66(100.0)$ & \\
\hline Total & $125(74.9)$ & $42(25.1)$ & $167(100.0)$ & \\
\hline \multicolumn{5}{|c|}{ Violent peer group } \\
\hline Male & $69(68.3)$ & $32(31.7)$ & $101(100.0)$ & \multirow{3}{*}{0.05} \\
\hline Female & $54(81.8)$ & $12(18.2)$ & $66(100.0)$ & \\
\hline Total & $123(73.7)$ & $44(26.3)$ & $167(100.0)$ & \\
\hline
\end{tabular}

* By Fisher's exact test

Table 2 shows the distribution of awareness about different types of violence among the study subjects. Awareness on the most common GBV among the study subjects was physical violence $(38.3 \%)$ followed by verbal $(29.9 \%)$, sexual $(20.4 \%)$, emotional $(7.2 \%)$ and economical (4.2\%). Awareness among females were higher than males regarding physical, emotional and sexual types of GBV but not statistically significant. However, males were aware about verbal type of GBV significantly higher (39.6\%) than females (15.2\%) $(\mathrm{p}=0.001)$.

Table 4: Gender wise awareness on health effects related to gender based violence.

\begin{tabular}{|c|c|c|c|c|}
\hline \multirow{2}{*}{$\begin{array}{l}\text { Health } \\
\text { Effects/ } \\
\text { Gender }\end{array}$} & \multicolumn{2}{|l|}{ Response } & & \multirow[b]{2}{*}{$\begin{array}{l}\text { 'P' } \\
\text { value }\end{array}$} \\
\hline & $\begin{array}{l}\text { Yes } \\
\text { No }(\%)\end{array}$ & $\begin{array}{l}\text { No } \\
\text { No }(\%)\end{array}$ & $\begin{array}{l}\text { Total } \\
\text { No }(\%)\end{array}$ & \\
\hline \multicolumn{5}{|c|}{ HIV/ AIDS } \\
\hline Male & $46(45.5)$ & $55(54.5)$ & $101(100.0)$ & \multirow{3}{*}{0.09} \\
\hline Female & $39(59.1)$ & $27(40.9)$ & $66(100.0)$ & \\
\hline Total & $85(50.9)$ & $82(49.1)$ & $167(100.0)$ & \\
\hline \multicolumn{5}{|c|}{ Unintended pregnancy } \\
\hline Male & $68(67.3)$ & $33(32.7)$ & $101(100.0)$ & \multirow{3}{*}{0.34} \\
\hline Female & $49(74.2)$ & $17(25.8)$ & $66(100.0)$ & \\
\hline Total & $117(70.1)$ & $50(29.9)$ & $167(100.0)$ & \\
\hline \multicolumn{5}{|c|}{ Abortion/ miscarriage } \\
\hline Male & $77(76.2)$ & $24(23.8)$ & $101(100.0)$ & \multirow{3}{*}{0.12} \\
\hline Female & $57(86.4)$ & $9(13.6)$ & $66(100.0)$ & \\
\hline Total & $134(80.2)$ & $33(19.8)$ & $167(100.0)$ & \\
\hline \multicolumn{5}{|c|}{ Depression } \\
\hline Male & $91(90.1)$ & $10(9.9)$ & $101(100.0)$ & \multirow{3}{*}{0.65} \\
\hline Female & $58(87.9)$ & $8(12.1)$ & $66(100.0)$ & \\
\hline Total & $149(89.2)$ & $18(10.8)$ & $167(100.0)$ & \\
\hline \multicolumn{5}{|c|}{ Suicidal ideations } \\
\hline Male & $84(83.2)$ & $17(16.8)$ & $101(100.0)$ & \multirow{3}{*}{0.58} \\
\hline Female & $57(86.4)$ & $9(13.6)$ & $66(100.0)$ & \\
\hline Total & $141(84.4)$ & $26(15.6)$ & $167(100.0)$ & \\
\hline \multicolumn{5}{|c|}{ Sleep disorders } \\
\hline Male & $76(75.2)$ & $25(24.8)$ & $101(100.0)$ & \multirow{3}{*}{0.04} \\
\hline Female & $58(87.9)$ & $8(12.1)$ & $66(100.0)$ & \\
\hline Total & $134(80.2)$ & $33(19.8)$ & $167(100.0)$ & \\
\hline \multicolumn{5}{|c|}{ Injuries to body } \\
\hline Male & $91(90.1)$ & $10(9.9)$ & $101(100.0)$ & \multirow{3}{*}{$0.13^{*}$} \\
\hline Female & $64(97.0)$ & $2(3.0)$ & $66(100.0)$ & \\
\hline Total & $155(92.8)$ & $12(7.2)$ & $167(100.0)$ & \\
\hline \multicolumn{5}{|c|}{ Fractures } \\
\hline Male & $74(73.3)$ & $27(26.7)$ & $101(100.0)$ & \multirow{3}{*}{0.04} \\
\hline Female & $57(86.4)$ & $9(13.6)$ & $66(100.0)$ & \\
\hline Total & $131(78.4)$ & $36(21.6)$ & $167(100.0)$ & \\
\hline \multicolumn{5}{|c|}{ Loss of vision } \\
\hline Male & $55(54.5)$ & $46(45.5)$ & $101(100.0)$ & \multirow{3}{*}{0.003} \\
\hline Female & $51(77.3)$ & $15(22.7)$ & $66(100.0)$ & \\
\hline Total & $106(63.5)$ & $61(36.5)$ & $167(100.0)$ & \\
\hline \multicolumn{5}{|c|}{ Loss of hearing } \\
\hline Male & $56(55.4)$ & $45(44.6)$ & $101(100.0)$ & \multirow{3}{*}{0.004} \\
\hline Female & $51(77.3)$ & $15(22.7)$ & $66(100.0)$ & \\
\hline Total & $107(64.1)$ & $60(35.9)$ & $167(100.0)$ & \\
\hline
\end{tabular}

Table 4 shows gender wise awareness on the health effects related to GBV. Females were significantly more aware than males regarding various health effects of 
GBV such as sleep disorders $(\mathrm{p}=0.04)$, fractures $(\mathrm{p}=0.04)$, loss of vision $(\mathrm{p}=0.003)$ and loss of hearing $(\mathrm{p}=0.004)$.

Awareness on warning signs of GBV among the study subjects is shown in figure 1. There are different warning signs which indicate the GBV victims. $95.5 \%$ female respondents and $89.1 \%$ male respondents agreed that scar marks over body were the major warning signs to screen GBV victims. The other important warning signs as per female respondents were depressed moods (90.9\%) and injuries $(90.9 \%)$.

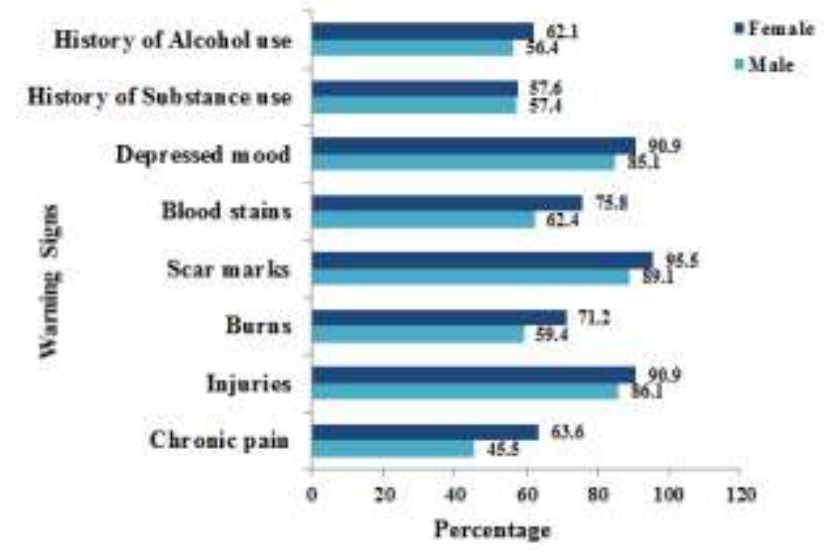

Figure 1: Bar diagram showing awareness on warning signs of GBV victims in the study population.

Awareness about the risk factors for becoming the victims of GBV among the study subjects according to gender is shown in table 3 . Females were significantly more aware than males about risk factors of GBV such as male control in decision making $(p=0.002)$, financial dependence on the husband/ spouse $(\mathrm{p}=0.02)$, poverty/ low socio economic status (SES) $(\mathrm{p}=0.02)$.

\section{DISCUSSION}

In the present study, out of 167 Group D workers, $30.7 \%$ males were aware about Domestic Violence Act 2005 as compared to $15.2 \%$ among females and this was found to be statistically significant $(\mathrm{p}=0.02)$. Awareness regarding Sexual Harassment Act 2013, however, did not show significant association between the gender $(p=0.32)$. A study from Nepal observed that $61.3 \%$ women were unaware of any laws related to GBV and only $13 \%$ were aware of a specific law against domestic violence. 18 The awareness about most common type of violence among the study subjects was physical violence $38.3 \%$ followed by verbal $29.9 \%$, sexual $20.4 \%$, emotional $7.2 \%$ and economical $4.2 \%$. Awareness among females were higher than males regarding physical, emotional and sexual types of GBV but not statistically significant. However, males were aware about verbal type of GBV significantly higher $39.6 \%$ than females $15.2 \%$ ( $\mathrm{p}=0.001)$. According to NFHS3 survey, $35 \%$ of women aged 15-49 in India have experienced physical or sexual violence. ${ }^{19}$ The overall prevalence of physical, psychological, sexual and any form of violence among women of Eastern India were $16 \%, 52 \%, 25 \%$ and $56 \%$ respectively. ${ }^{20}$ The lifetime prevalence of physical assault and sexual coercion was found to be $34 \%$ and $4 \%$, respectively, in a rural country of western China. ${ }^{21}$ In India women's experience of physical or sexual violence ranges from a low of $6 \%$ in Himachal Pradesh to $40 \%$ or more in Rajasthan, Madhya Pradesh and Tripura, and to a high of $56 \%$ in Bihar. ${ }^{19}$ A study done in Bengaluru slums by Rocca $\mathrm{CH}$ et al found over half (56\%) of the study participants reported having ever experienced physical domestic violence. ${ }^{14}$ A study from Nepal shows that Emotional violence (40.4\%) was most commonly reported, followed by physical violence $(26.8 \%)$, sexual violence $(15.3 \%)$ and economic abuse/ violence $(8 \%){ }^{18}$ A study conducted among Afghan refugees shows that $50 \%$ and above women experienced physical violence and $32 \%$ experienced emotional violence in their life time. $^{22}$

In this study there was no significant association between the age group and awareness about GBV (data not shown). Since the past 2-3 decades, there is lot of efforts made by the NGO's, social activist and by the Government to curb domestic violence against women and safe guard her constitutional rights, but still there is a rise in domestic violence. If applied correctly the Protection of Women against Domestic Violence Act 2005 (PWDVA) is a powerful act. ${ }^{13}$ It will still remain worthless if there is lack of awareness amongst the people.

In this study, we analysed the awareness on various risk factors of GBV. It affects people of all socioeconomic backgrounds and education levels. Our study shows that females were significantly more aware than males about risk factors of GBV such as male control in decision making ( $\mathrm{p}=0.002)$, financial dependence on the husband/ spouse $(\mathrm{p}=0.02)$, poverty/ low socio economic status (SES) $(\mathrm{p}=0.02)$. Use of alcohol and substance use were not significantly associated with the gender of the respondents. The association of family income and GBV was found to be highly significant in other studies conducted in India. ${ }^{15,17}$

GBV has severe reproductive health impacts, including gynecological problems, unintended pregnancies, and perhaps most gravely, increased risk of maternal mortality and STIs, including HIV. Studies show that physical abuse occurs at some point during approximately 4 percent to 15 percent of pregnancies in countries as varied as the United States, Canada, Sweden, the United Kingdom, and South Africa. ${ }^{23,24}$ In fact, a 2001 study in the United States found that pregnant and recently pregnant women were more likely to be victims of homicide than to die of any other cause. ${ }^{25}$ Our study shows that females were significantly more aware than males regarding various health effects of GBV such as sleep disorders $(\mathrm{p}=0.04)$, fractures $(\mathrm{p}=0.04)$, loss of vision $(\mathrm{p}=0.003)$ and loss of hearing $(\mathrm{p}=0.004)$. An injury 
to the body is one of the important factors related to GBV, which was responded by $92.8 \%$ of the Group D workers in our study. Abortion/ miscarriage, depression, anxiety, suicidal ideation and sleep disorders were also important health effects known to $>80 \%$ of the respondents.

There are different warning signs which indicate the patient may be the victim of GBV. Our study shows that, $95.5 \%$ female respondents and $89.1 \%$ male respondents agreed that scar marks over body are the major warning sign to screen GBV victims. Depressed moods and injuries are the other two important warning signs for the detection of GBV victims identified by female respondents. There are only a couple of studies that point to the fatal consequences of gender-based violence against women. In Western India, a study in 400 villages and seven hospitals found that $15.7 \%$ of the pregnancy related deaths in the community series and $12.9 \%$ in the community were because of domestic violence. Another study by Seshu and Bhosale in Western India related to dowry deaths and intentional injuries found that $59 \%$ of women had experienced physical violence, $28 \%$ mental torture, $10 \%$ molestation by family members and perversity, and 3\% starvation.

The collection of data related to gender based violence has limitations in terms of non-response by the participants accurately because of the sensitive nature of the topic and participants may not express their views openly, as they think that their responses might damage the reputation of themselves and their families. Sometimes in this type of research, participants may also report the behaviour that is believed to be consistent with their culture, rather than the actual study included only the awareness about GBV. The findings of the study indicate the need for raising awareness among the group D staff in the study hospitals about gender based violence so that they can contribute effectively in dealing with cases of GBV in the health set up.

\section{ACKNOWLEDGMENTS}

We sincerely acknowledge Ms Tripti, Ms Meena Kumari, $\mathrm{Mr}$ Amrish Ku Niranjan and Ms Momina Khan for their contribution in collection of data for this study. We also wish to acknowledge all the volunteers for their participation in the study.

Funding: Indian Council of Medical Research (ICMR), New Delhi, India

Conflict of interest: None declared

Ethical approval: The study was approved by the Institutional Ethics Committee

\section{REFERENCES}

1. Claudia GM, Henrica AFM, Ellsberg ME, Heise L, Watts C. WHO multi-country study on women's health and domestic violence against women. Geneva, Switzerland: WHO.2005.

2. Shwetha TM, Ashok J, Rajanna MS, Rajesh SS, Iyengar K. Intimate partner violence among ever married Group-D women workers in a medical institution. Int $\mathrm{J}$ Community Med Pub Health. 2016;3:619-24.

3. Gender based violence: an impediment to sexual and reproductive health. The Women's advocacy Session, IPPF Members Assembly, Prague. IPPF. 1998. Available at: http://www.ippf.org/resource/gbv/ma98. Accessed on $30^{\text {th }}$ Decmber 2015.

4. Jacobs T, Jewkes R, Vezimfilho. A model for health sector response to gender violence in South Africa. Int Journal of Gynae Obs. 2002;78(1):51-6.

5. Harold G, Koenig MD. Health care and faith communities. Journal of Gen Int Med. 2003;18(11): 962-3.

6. Mahapatro M, Gupta R, Gupta V, Kundu A. Interpersonal violence as risk factor for women's sexually transmitted infection and reproductive health consequences in India: a community based study. Journal of Pub Health.2011;1-5.

7. Willman. Valuing the impacts of domestic violence: a review by sector. The World Bank: Washington, DC, 2008.

8. Heise L, Ellsberg M, Gottemoeller M. Ending violence against women. Johns Hopkins University School of Public Health. Center for Communications Programs. Population Information Program, 1999.

9. World health organization. Understanding and addressing violence against women, www.apps.who.int/iris/bitstream/10665/77432/1/W HO_RHR_12.36_eng.pdf.

10. Kishore J. The protection of women from domestic violence act, $2005 \mathrm{In}$ : National health programs of India, $10^{\text {th }}$ ed. Century publications, New Dehli; 2012.

11. Claudia GM, Jansen HA, Ellsberg M, Heise L, Watts $\mathrm{CH}$. Prevalence of intimate partner violence: findings from the WHO multi country study on women's Health and domestic violence. Lancet. 2006;368:1260-9.

12. World Health Organization. Violence against women available at www.who.int.in.

13. Kadam SS, Chaudhari VA. Domestic violence against woman: past, present, future. J Indian Acad Forensic Med. 2011;33(3):261-6.

14. Rocca CH, Rathod S, Falle T, Pande RP, Krishnan S. Challenging assumptions about women's empowerment: social and economic resources and domestic violence among young married women in urban South India. Int J Epidemiol. 2009;38:577-85.

15. Mahapatro M, Gupta RN, Gupta V. The risk factor of domestic violence in India. Indian J Community Med. 2012;37(3):153-7. 
16. Jejeebhoy SJ, Cook RJ. State accountability for wife beating: the Indian challenge. Lancet. 1997;349:S10-2.

17. Jeyaseelan L, Kumar S, Neelakantan N, Peedicayil A, Pillai R, Duvvury N. Physical spousal violence against women in India: some risk factors. J BiosocSci. 2007;39:65-70.

18. Government of Nepal. A study on gender based violence conducted in selected rural districts of Nepal. Available at: URL: https://asiafoundation.org/resources/pdfs/OPMCMG ECUGBVResearchFinal.pdf. Accessed on $7^{\text {th }}$ April 2016.

19. Ministry of health and family welfare. National family welfare survey- 3, India fact Sheet 2005-06 Available at www.nfhsindia.org.

20. Babu BV, Kar SK. Domestic violence against women in eastern India: a population based study on prevalence and related issue. BMC Pub Health. 2009;9:129.

21. Ackerson LK, Kawachi I, Barbeau EM, Subramanian SV. Effects of individual and proximate educational context on intimate partner violence: a population-based study of women in India. Am J Public Health. 2008;98:3.

22. Gender based violence among Afghan refugees. Available http://internationalmedicalcorps.org/document.doc?i $\mathrm{d}=65$. Accessed $7^{\text {th }}$ April 2016.

23. Campbell JC, Soeken KL. Forced Sex and intimate partner violence: effects on women's risk and women's health. Violence against women. 1999;5(9):1017-35.

24. Jewkes R, Vundule C, Maforah F, Jordaan E. Relationship dynamics and adolescent pregnancy in south africa. Soc Sci Med. 2001;52(5):733-44.

25. Isabelle $H$. Enhanced surveillance for pregnancy related mortality: maryland, 1993-1998. JAMA. 2001;285:1455-9.

Cite this article as: Singh MM, Garg S, Dash R, Kumar R, Jain N, Sharma N, Anand T. Study on awareness regarding gender based violence among group D workers in public hospitals of Delhi, India: a gender perspective. Int J Community Med Public Health 2016;3:1510-5. 